Article

\title{
Operation Adaptation of Moving Bed Biomass Combustors under Various Waste Fuel Conditions
}

\author{
Mohammad Hosseini Rahdar * and Fuzhan Nasiri \\ Department of Building, Civil \& Environmental Engineering, Concordia University, Montreal, \\ QC H3G 1M8, Canada; fuzhan.nasiri@concordia.ca \\ * Correspondence: hoseinirah.m@gmail.com
}

Received: 20 October 2020; Accepted: 24 November 2020; Published: 1 December 2020

check for updates

\begin{abstract}
This paper analyzes a moving grate biomass boiler operating with three alternative waste fuels, including biomass pellets, wood waste, and refuse-derived fuel (RDF) from a combination of thermal, economic, and environmental perspectives. The focus of this paper is on system functionality adaptation to retrofit the current systems operational conditions. A one-dimensional numerical bed model integrated with a black-box overbed model was developed to carefully investigate the fuel bed's thermal characteristics, as well as the boiler's output. According to the results, the system operates more efficiently under the biomass pellets feeding and annually generates 548 GJ heat, while it drops significantly in other scenarios. The system was economically evaluated based on a 25 -year life cycle cost analysis. Subsequently, an internal rate of return (IRR) of $36 \%$ was calculated for biomass pellets, while the value reduced by $50 \%$ and $27 \%$ regarding wood waste and RDF, respectively. The fuel cost was identified as the main contributor to the total life cycle cost of the heating system, regardless of which feeding fuel was utilized. A long-term environmental impacts assessment of the boiler operation emerged, to show how plant-based fuels can significantly decrease the impacts of climate change that have originated from fossil fuel usage. The current study concludes that all the proposed scenarios are feasible to different degrees, and can extensively benefit a diverse set of energy sectors.
\end{abstract}

Keywords: moving bed biomass boiler; numerical modeling; heat generation; economic analysis; LCA

\section{Introduction}

Thanks to advancements in technology, in recent decades, renewable energy has been deemed a very practical alternative to using conventional fossil fuels to supply cleaner sustainable energy systems [1]. Biomass, a carbon-based renewable resource, is capable to replace fossil fuels with the least modification in conventional facilities compared to other renewable resources. Among all possible biomass conversion processes, yet direct combustion is the most commercialized one [2,3]. Other advancing technologies, such as anaerobic digestion (AD), hydrothermal carbonization (HTC), as well as hydrothermal gasification (HTG) are generally less commercialized, owing to poor infrastructure of raw fuel supply, high operational and capital cost, and mostly are in prototype-scale so far [2-5].

Moving bed, fluidized bed, and pulverized fuel combustors are identified as the commercialized combustion technologies to burning biomass fuels. Based on a certain application, each of the aforementioned systems can be a more fitting choice, as discussed elsewhere [6]. In the course of small-scale purposes, moving grate furnaces are one of the most highly utilized approaches to burning raw and treated biomass waste. While, in addition, within the small to medium scale applications, the moving grate furnaces require less fuel preparation.

Currently, research has been conducted in order to modify the combustion system efficiency, as well as the contaminant emission issue that are associated with these systems [7-12]. Throughout 
the literature, the majority of the developed biomass combustion models were exercised in micro-scale system analyses in order to understand the biomass combustion properties more comprehensively [13-15]. These models were rarely governed as a system analysis tool in order to evaluate the functional system outputs and required operation adaptation for more efficient combustion. For example, a numerical model was developed by Zhou et al. [8] to study the effect of variant excess air ratio on combustion efficiency. The authors concluded that, under $\mathrm{O}_{2}$ enriching combustion, which is defined as an increase in air flow rate from the stoichiometric condition to a higher fraction; the optimum combustion improvement is achieved when the $\mathrm{O}_{2}$ volume fraction raises from $21 \%$ to $25 \%$. Meanwhile, the maximum bed temperature is restricted to $1400 \mathrm{~K}$. Similarly, bed and overbed zones were integrated on the same 3D grid, while the bed zone modeled through a porous medium [16]. The model then characterized a flow pattern and a specific temperature, as well as, pollutant profiles in the combustion chamber. Flame temperature, species concentration, and ignition front velocity for a packed-bed biomass combustor under $\mathrm{CO}_{2}$-rich condition was analyzed using an integrated $1 \mathrm{D}$ bed model into a 3D overbed model via Karim et al. [17]. The $\mathrm{CO}_{2}$-rich combustion indicates recycling flue gas as a fraction of primary air flowing into the fuel bed. The ignition front rate sped up to almost double the rate with $\mathrm{CO}_{2}$-rich air feed conditions. A connected 1D bed model and 3D overbed model was developed to cope with how different quality fuel influenced operations [18]. Larger high-temperature combustion zones were observed as a result of higher quality fuel, and, thus, consequently higher system efficiency. The effect of biomass fuel compositions variability on combustion properties in a moving grate combustor was studied through an independent bed model coupled with a simplified overbed combustion model [19]. The results demonstrated a major impact of composition variability on ignition front rate, conversion time, and output heat flux, as well as a minor impact on the flame temperature. Existing models help engineers to design for a better biomass combustion, which is quite necessary for technology advancement. Meanwhile, system analysis using black-box model without paying attention to operational detail can be beneficial only for general decision making [20]. However, for many of the domestic and industrial facility's users, it is impractical to take advantage of such modeling applications. In other words, for example, it is crucially important for them to know how system operation should be readjusted when switching from variant feeding fuels for example from specific biomass pellets to wood chips. In addition, what the economic and ecosystem consequences of this fuel switching action are.

In this paper, functional thermal properties of a moving bed biomass boiler fed with three specific waste-based fuels: biomass pellets, wood waste, and refuse-derived fuel (RDF), are carefully determined through a routine of one-dimensional transient numerical bed model integrated with an overbed black-box model. In this study, instead of focusing on biomass combustion diagnosis and micro-scale combustion analyses, we propose the required adjustments to facilitate system operation settings when switching between the proposed fuels. Furthermore, to illustrate the long-term economic and environmental impacts of system operation with each fuel, life cycle costing (LCC) and life cycle analysis (LCA) are also conducted. It should be noted that moving grate boilers can concurrently burn different fuel types, such as those that are applied in this study. In consequence, the results of this article are highly informative for system users.

\section{Modeling Procedure}

The process of biomass combustion inside the packed bed deals with thermochemical reactions consisting of drying, devolatilization, and char combustion. To some degree, this is a complicated process that still has many unknown variables. The existing 1D, 2D, and 3D empirical models can predict the actual combustion process from an engineering standpoint.

Drying as an endothermic reaction has a significant impact on combustion. Many studies have proved that higher moisture content of biomass particles can diminish thermal performance and increase contaminant emissions [15,21-23]. By analyzing the literature, where different drying models can be identified, Arrhenius and heat sink models have been applied in recent studies. The influence 
of moisture content of different particle shapes on drying behavior was examined using the Arrhenius and heat sink models by Khodaei et al. [24]. Through a lack of experimental data regarding particle de-moisturization, the heat sink model exhibited more compatible results that was opted for in this work. Pyrolysis occurs after the evaporation of the initial moisture content. This includes several interrelated parallel reactions that initiate at disparate temperatures and begin at a higher rate than drying. Here, the fuel mass of the bed profoundly diminishes while volumetric fuel bed reduction is insignificant. Varied pyrolysis models have been listed in Reference [25], although only a few of them have been recently applied in the biomass conversion models due to their relative complexity and inaccuracy. Among all, the model with three parallel reaction-terms has been dominantly utilized, as it has a trade-off between computational cost and precision, and, therefore, simulates the devolatilization process in this article. The most complex reactions occur during char combustion, in which both diffusion and thermal mechanisms compete to overtake the reaction. It is imagined that char reaction consists of four overlapping reactions [25], while, in most of the research, the fourth reaction, the reaction of carbon with hydrogen, is overlooked, due to its negligible effect on the whole process. For a detailed description of each subprocess and the corresponding models, Reference [26] is recommended.

Fuel bed simulation has been conducted through varying techniques in the publications. They can be categorized as empirical bed models, separate bed models, discrete particle models (DPM), and porous medium bed models. A more thorough explanation of each technique can be found through further research beyond the scope of this article [27]. The separation of fuel bed and overbed zone modeling is the most preferred strategy in biomass furnace modeling, in which it facilitates the sensitive and in-depth analysis of solid particle conversion. Instead of 3D modeling of fuel beds, 2D models (or 1D transient models) are usually governed, because fields gradient in the z-direction of bed zones are insignificant. According to the literature, this strategy can be implemented by utilizing variant approaches, including the single-particle model, the continuous medium model, and the particle-resolved model. The single-particle model delivers proper results for a fluidized bed system, because the proposed particles have uniform boundary conditions, while in the moving grate combustors, particles have non-uniform boundary conditions. The particle-resolved modeling has modified the problems with single-particle molding, however, the computational cost of this is quite high. In this article, the continuous medium model is governed to simulate fuel conversion, where it has a fair trade-off between accuracy and computational cost. It should be mentioned that this method could raise dispersion in results when large-size particles are deployed.

Figure 1 visualizes the fuel particles arrangement under the actual condition and continuous medium modeling approach along with heat transfer mechanisms inside the fuel bed. From this figure, the main limitation of the continuous medium model is to neglect radiation between particles inside the fuel bed. The furnaces side walls are assumed to be insulated so that no heat leakage can occur from the fuel bed zone to the outside of the walls. Reactions happen in the vertical direction inside the fuel bed, whereby the horizontal gradient is insignificant. The one-dimensional transient model is executed, in order to eliminate the complexity of two-dimensional modeling. This method, the so-called walking column, tracks changes in a tiny column of the fuel bed from the opening of the grate until all fuel in the column is consumed [28]. The column is split into small cells, as each cell consists of the solid and gas phase and is updated during the conversion process. The solid phase initially includes a predefined amount of moisture, volatile, and char, which are gradually depleted during the process until all solid parts convert to gaseous elements. A one-dimensional walking column strategy which models a 2D steady-state fuel bed geometry, coupled with overbed black-box modeling, is visualized in Figure 2. Heat flux is then obtained from oxidation of combustible gases in the overbed zone. 
in practice:

Wall

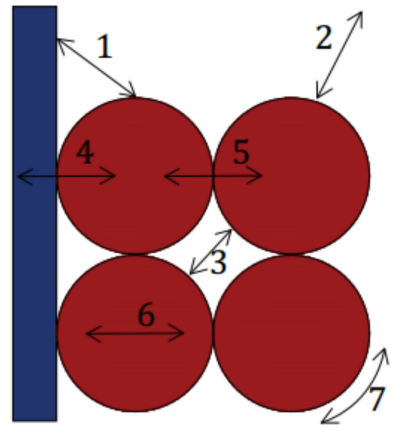

Radiation:

1. wall-particle

2. gas-particle

3. particle-particle Conduction: simulation:

insulation

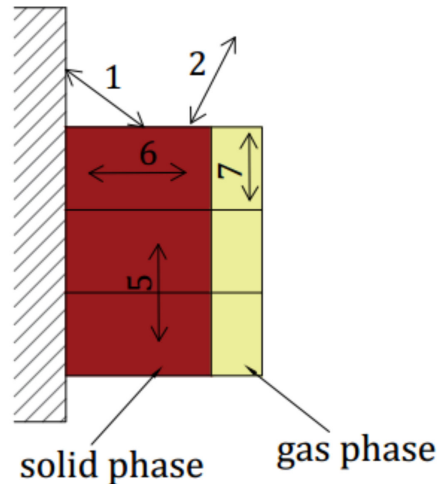

Conduction:

4. wall-particle

5. particle-particle

6. inside particle

Convection:

7. gas-particle

Figure 1. Heat transfer mechanisms in packed bed and continuous medium modeling.

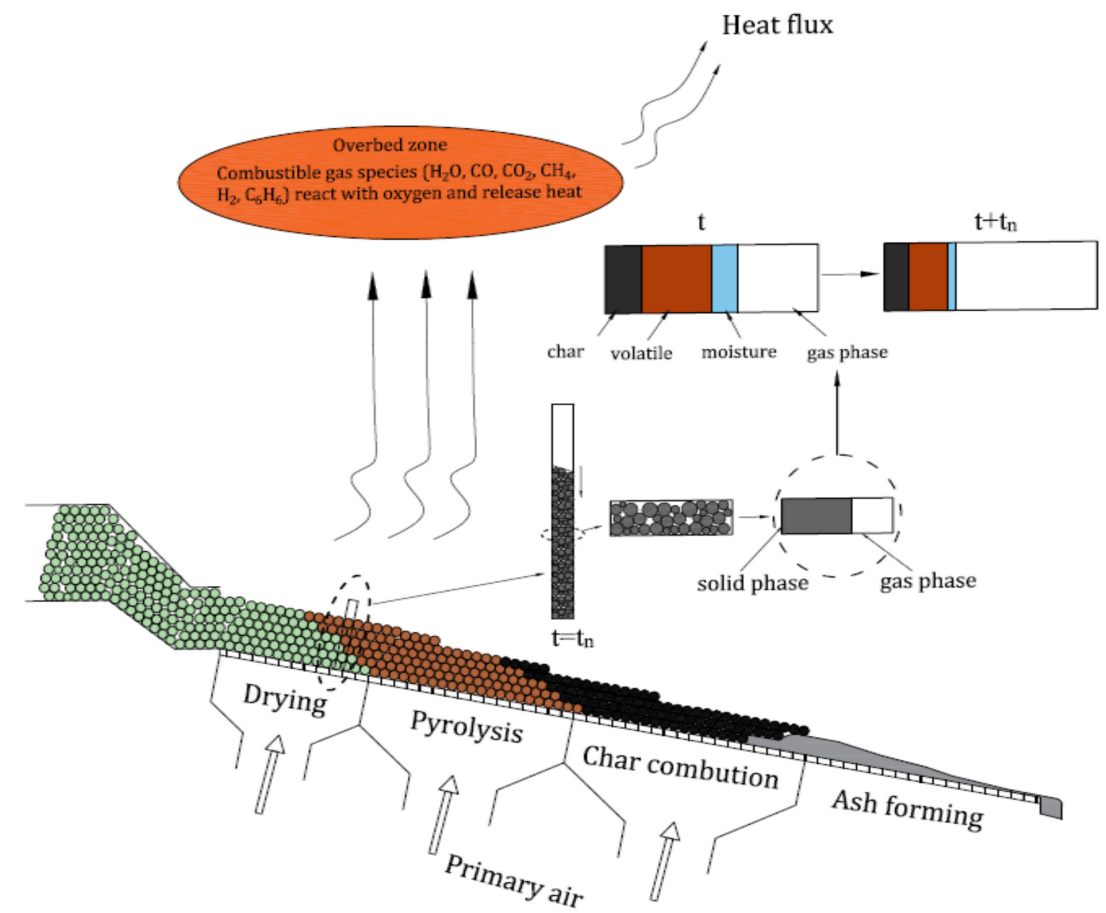

Figure 2. One-dimensional walking column method for moving-grate biomass combustor modeling.

The solid and gas phase governing equations used in this work are demonstrated in Table 1. Other information related to the modeling, such as kinetic formula of subprocesses, coefficients of specific heat, conductivity, source terms of governing equations, and so on, are presented in Table 2. Gas pressure drop for laminar flow in the packed fuel bed is also introduced in Table 2, where $\mathrm{L}$ is the fuel bed height, $g_{c}$ is the gravitational constant, $\varepsilon$ is effective porosity, $\mu$ air is absolute viscosity, $v$ is air velocity, $d_{p}$ is effective particle diameter, and $\rho$ is air density [29]. 
Table 1. Conservation equations regarding the solid and gas phase of fuel packed bed conversion.

\begin{tabular}{cc}
\hline & Gas-Phase Governing Equations \\
Mass & $\frac{\partial}{\partial t}\left(\phi \rho_{g}\right)+\nabla\left(\phi \rho_{g} v_{g}\right)=S_{\text {mois }}+S_{\text {vol }}+S_{\text {char }}$ \\
Momentum & $\frac{\partial}{\partial t}\left(\phi \rho_{g} v_{g}\right)+\nabla\left(\phi \rho_{g} v_{g} v_{g}\right)=-\nabla P_{g}+F\left(\bar{v}_{g}\right)$ \\
Energy & $\frac{\partial}{\partial t}\left(\phi \rho_{g} c_{p, g} T_{g}\right)+\nabla\left(\phi \rho_{g} v_{g} c_{p, g} T_{g}\right)=\nabla\left(\lambda_{g} \nabla T_{g}\right)+h S\left(T_{s}-T_{g}\right)+S_{g}$ \\
Species & $\frac{\partial}{\partial t}\left(\phi \rho_{g} Y_{i}\right)+\nabla\left(\phi \rho_{g} v_{g} Y_{i}\right)=\nabla\left(\phi \rho_{g} D_{g, i} \nabla Y_{i}\right)+\phi S_{g, i}$ \\
& Solid-phase governing equations \\
Mass & $\frac{\partial}{\partial t}\left((1-\phi) \rho_{s}\right)=-S_{\text {mois }}-S_{\text {vol }}-S_{\text {char }}$ \\
Energy & $\frac{\partial}{\partial t}\left((1-\phi) \rho_{s} c_{p, s} T_{s}\right)=\nabla \cdot\left(\lambda_{e f f} \nabla T_{s}\right)+h S\left(T_{g}-T_{s}\right)+S_{s}+S_{\text {rad }}$ \\
\hline
\end{tabular}

Table 2. Modeling coefficients and fuel properties.

\begin{tabular}{|c|c|c|c|}
\hline Parameter & & Value & REF. \\
\hline Drying & $\frac{d \rho_{M}}{d t}=$ & $\begin{array}{cl}-0.5 \frac{\rho_{p} C_{p}\left(T_{s}-T_{\text {evap }}\right)}{L H \Delta t}, & T_{S} \geq T_{\text {evap }} \\
0 & \text { Otherwise }\end{array}$ & \\
\hline \multirow[t]{3}{*}{ Pyrolysis kinetic rate, $1 / \mathrm{s}$} & $k_{V, 1}$ & $1.44 \times 10^{4} \exp \left(-88.6 \times 10^{3} / R T_{s}\right)$ & [9] \\
\hline & $k_{V, 2}$ & $4.13 \times 10^{6} \exp \left(-112.7 \times 10^{3} / R T_{s}\right)$ & [9] \\
\hline & $k_{V, 3}$ & $7.38 \times 10^{5} \exp \left(-106.5 \times 10^{3} / R T_{s}\right)$ & [9] \\
\hline \multirow[t]{4}{*}{ Char kinetic rate, $1 / \mathrm{s}$} & $k_{C, 1}$ & $4 \times 10^{3} \exp \left(-8 \times 10^{4} / R T_{s}\right)$ & [30] \\
\hline & $k_{C, 2}$ & $3.6 \times 10^{4} \exp \left(-1.76 \times 10^{8} / R T_{s}\right)$ & [30] \\
\hline & $k_{C, 3}$ & $3.42 \exp \left(-1.297 \times 10^{8} / R T_{s}\right)$ & [30] \\
\hline & $\Omega_{C}$ & $\frac{2\left(1+4.3 \exp \left(-3390 / T_{\mathrm{s}}\right)\right)}{2+4.3 \exp \left(-3390 / T_{\mathrm{s}}\right)}$ & [31] \\
\hline \multirow[t]{8}{*}{ Diffusion coefficient, $\mathrm{m}^{2} / \mathrm{s}$} & $D_{H 2 O-a i r}$ & 0.219 & [32] \\
\hline & $D_{H 2-a i r}$ & 0.611 & [32] \\
\hline & $D_{\mathrm{CO} 2-a i r}$ & 0.138 & [32] \\
\hline & $D_{\mathrm{CO}-a i r}$ & 0.162 & [32] \\
\hline & $D_{\mathrm{CH} 4-\text { air }}$ & 0.196 & [32] \\
\hline & $D_{\mathrm{O} 2-a i r}$ & 0.178 & [32] \\
\hline & $D_{\mathrm{C} 6 \mathrm{H} 6-a i r}$ & 0.119 & [32] \\
\hline & Updating term & $D_{A B}=D_{A B, r e f}\left(\frac{T_{g}}{T_{r e f}}\right)^{1.75}$ & [33] \\
\hline \multirow[t]{4}{*}{ Enthalpy of reaction, $\mathrm{J} / \mathrm{kg}$} & $\begin{array}{l}\mathrm{H}_{\mathrm{M}} \\
\mathrm{H}_{\mathrm{Y}}\end{array}$ & $\begin{array}{c}-2.2465 \times 10^{6} \\
-3 \times 10^{5}\end{array}$ & $\begin{array}{l}{[30]} \\
{[30]}\end{array}$ \\
\hline & $\mathrm{H}_{\mathrm{C}, \mathrm{O} 2}$ & $\left(2\left(\Omega_{C}-1\right) 9.8 \times 10^{6}+\left(2-\Omega_{C}\right) 33.1 \times 10^{6}\right) / \Omega_{C}$ & [30] \\
\hline & $\mathrm{H}_{\mathrm{C}, \mathrm{CO} 2}$ & $-14.3833 \times 10^{6}$ & [30] \\
\hline & $\mathrm{H}_{\mathrm{C}, \mathrm{H} 2 \mathrm{O}}$ & $-10.95 \times 10^{6}$ & [30] \\
\hline Gas heat capacity. J/kg K & $C_{p, g}$ & $\left(0.99+1.22 \times 10^{-4} T_{g}-5.68 \times 10^{3} T_{g}^{-2}\right) \times 10^{3}$ & [34] \\
\hline Gas thermal conductivity, W/m K & $\lambda_{g}$ & $4.8 \times 10^{-4} \mathrm{~T}_{g}^{0.717}$ & [35] \\
\hline Solid heat capacity. J/kg K & $C_{p, s}$ & $\sum_{k} Y_{k} C_{p, k}, k=$ drying, pyrolysis, char burning & [30] \\
\hline Effective solid conductivity, W/m & $\lambda_{e f f}$ & $\sum_{k}^{k} Y_{k} \lambda_{k}, k=$ drying, pyrolysis, char burning & [30] \\
\hline Bed void fraction & $\phi$ & 0.42 & [30] \\
\hline Emissivity & $\omega$ & 0.85 & [30] \\
\hline Gas pressure drop in packed bed, $\mathrm{Pa}$ & $\frac{\Delta P}{L} g_{c}$ & $=180 \frac{(1-\varepsilon)^{2}}{\varepsilon^{3.6}} \frac{\mu v}{d_{p}^{2}}+1.8 \frac{(1-\varepsilon)}{\varepsilon^{3.6}} \frac{\rho v^{2}}{d_{p}}$ & [29] \\
\hline
\end{tabular}

During the conversion of fuels, volumetric shrinkage of single biomass particles causes the fuel bed to decay, which is referred to as fuel bed porosity [36]. An explicit approach is used in this article, so that the particle mass consumption inside the grid is continuously observed until the all grid mass is depleted. In each iteration, each grid is filled by its upper grid mass. In this way, bed shrinkage is fairly traceable while biomass conversion proceeds [37]. $a_{1}, a_{2}$, and $a_{3}$ imply a shrinkage factor of drying, pyrolysis and char oxidation, at which values $0.1,0.15$, and 0.75 are assigned, respectively.

$$
\frac{V}{V_{0}}=1-a_{1}\left(M_{0}-M\right)-a_{2}\left(V M_{0}-V M\right)-a_{3}\left(C_{0}-C\right)
$$

Outflowing gas species from solid fuel conversion are presumed to be $\mathrm{CO}, \mathrm{CO}_{2}, \mathrm{CH}_{4}, \mathrm{H}_{2}, \mathrm{H}_{2} \mathrm{O}$, and $\mathrm{C}_{6} \mathrm{H}_{6}$, whereby some react with oxygen mainly in the overbed zone. To quantify the fraction of 
volatile gases during combustion, the experimental results of another publication were employed [38]. Homogeneous gas-phase reactions [39], together with the corresponding enthalpy of reaction, are presented in Equations (2)-(5). The overbed gas-phase reactions along with the in-bed char combustion eventually form the source of heat generation in the combustion chamber. The accumulation of all the previously mentioned reactions are then accounted for in heat flux calculation.

$$
\begin{array}{rlrl}
\mathrm{H}_{2}+\frac{1}{2} \mathrm{O}_{2} & \rightarrow \mathrm{H}_{2} \mathrm{O} & \Delta H & =-241.82[\mathrm{~kJ} / \mathrm{mol}] \\
\mathrm{CH}_{4}+\frac{3}{2} \mathrm{O}_{2} \rightarrow \mathrm{CO}+2 \mathrm{H}_{2} \mathrm{O} & \Delta H & =-464.395[\mathrm{~kJ} / \mathrm{mol}] \\
\mathrm{CO}+\frac{1}{2} \mathrm{O}_{2} \rightarrow \mathrm{CO}_{2} & \Delta H & =-283[\mathrm{~kJ} / \mathrm{mol}] \\
\mathrm{C}_{6} \mathrm{H}_{6}+\frac{9}{2} \mathrm{O}_{2} \rightarrow 6 \mathrm{CO}+3 \mathrm{H}_{2} \mathrm{O} & \Delta H & =-1471.29[\mathrm{~kJ} / \mathrm{mol}]
\end{array}
$$

\section{Solution and Validation}

The finite difference method (FDM) is employed to discretize the conservation equations based on the given solution algorithm in Figure 3. FDM is a well-documented method suits the simple geometries. A fully implicit scheme backward difference in time and the central difference in space (BTCS) is opted for, in order to resolve the energy equation for the solid phase (heat equation), an upwind scheme for the gas-phase mass and momentum equations (advection equation), by using a BTCS scheme. Finally, an upwind scheme for the gas-phase energy and species equations (advection-diffusion equation) using the backward difference in time, the forward difference in first-order derivative term, and central difference for the second-order derivative term. Although the selected schemes are unconditionally stable, the accuracy of the solution will be protected by choosing the proper step size. Varied time step $\left(10^{-2}\right.$ to $\left.10^{-3} \mathrm{~s}\right)$ has opted for the solution along with 100 grid cells for the walking column. As most elements of the time-space matrix were zero, a sparse matrix method was used to speed up the solution procedure. The Python software was applied to code the solution algorithm.

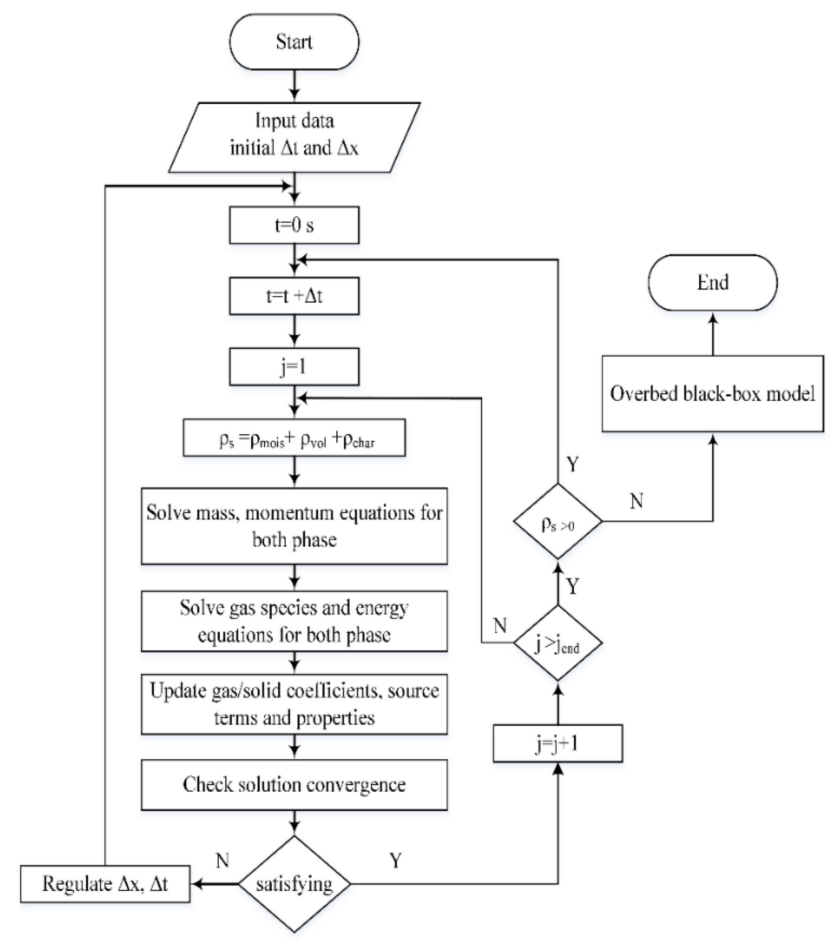

Figure 3. Solution algorithm for biomass combustor model. 
Bed temperature and mass loss profiles concerning the developed model were validated versus two separate experiments implemented on packed-bed biomass combustors [40,41]. From Figure 4, there is a satisfactory agreement between the model and experiments, unless there is a reasonable deviation, caused by inherent modeling error, model assumption, measuring error, etc.

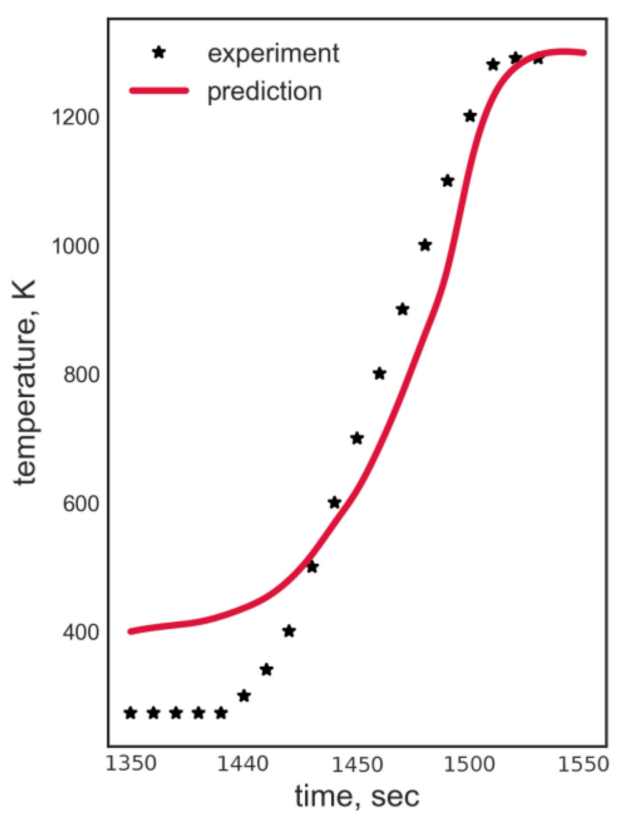

(a)

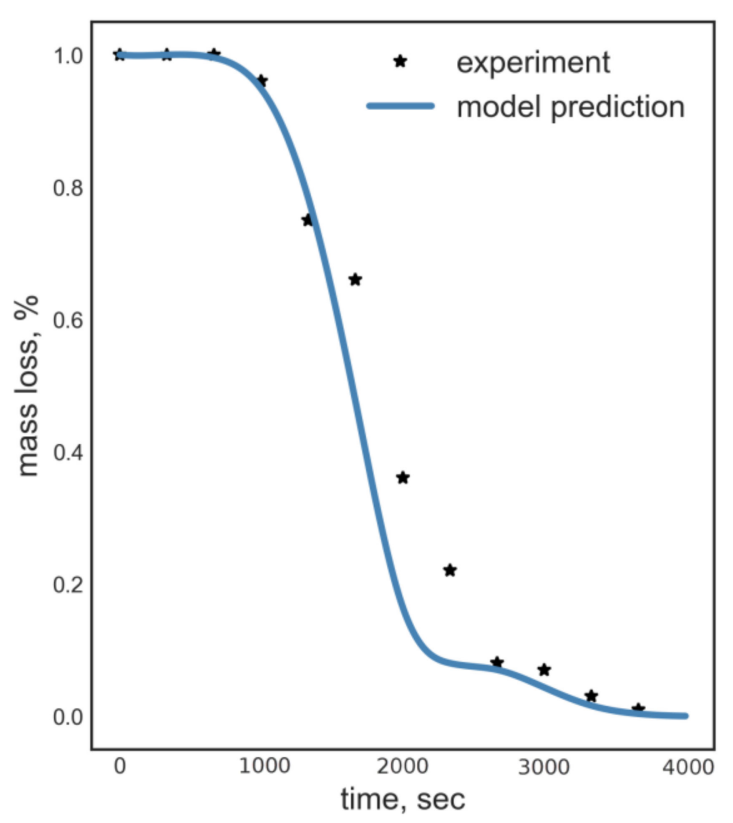

(b)

Figure 4. Model validation: (a) temperature evolution versus Reference [40], (b) mass loss versus Reference [41].

The dispersion between the temperature profile in terms of the experiments and model predictions within the drying stage can be interpreted in this way: the fuel moisture resided inside the particle pores absorbs a high proportion of the heat flowing from the overbed zone. In other words, most of the absorbed heat by particle in beginning step of conversion is used to increase moisture temperature, therefore, the particle surface temperature change is much slower. In doing so, the inside particle temperature rises, while the outer surface temperature, which the thermocouple measures, does not rise at the same rate as inside. This is deemed a limitation of the fuel bed experiment. Additionally, the predicted fuel bed conversion obtained by current simulation is in line with an earlier experiment, based on a study by Yin et al. [42], showing the contribution of drying, devolatilization, and char burnout in different lengths of a moving grate.

\section{Results and Discussion}

Before demonstrating and discussing the results, the key assumptions deployed through this study are highlighted here. For thermal analysis: 1. fuel bed is uniformly propagated in depth, and reaction rate is negligible in horizontal direction; 2. no air infiltration has been taken in calculation; 3. no heat loss from the wall occurs; 4 . primary and secondary air inject to the system at $373 \mathrm{~K}$. In terms of economic analysis: 1 . cost of technical maintenance has accumulated in capital cost; 2 . operational electricity cost of the feeder, conveyer, and air fans are equal for all scenarios; 3 . no government incentive has affected in cash flow diagram. Finally, for LCA: 1. the analysis boundary has been cut in a way that no manufacturing of equipment, ash landfill, and recycling process are considered; 2. the same supply location of raw fuel is selected for all scenarios. 


\subsection{System Adaptation Options}

In order to obtain required information for boiler adaptation when switching between fuels, combustion of three variant biomass waste fuels including biomass pellets, wood waste, and RDF were examined in a moving grate biomass boiler. Fuel composition characteristics together with corresponding stoichiometric air ratio and particle density are represented in Table $3[18,43,44]$. A biomass boiler with a bed height of $20 \mathrm{~cm}$, a grate length of $2 \mathrm{~m}$, and an initial overbed temperature of $1250 \mathrm{~K}$ were applied in this study. This overbed temperature is an initial estimation of overbed temperature and would be updated during the calculation. It would also converge to the actual value as combustion proceeds. The primary to secondary air ratio was set on an appropriate value of 40:60 according to the literature [45], along with the primary air temperature on $100{ }^{\circ} \mathrm{C}$ to accelerate drying.

Table 3. Fuel properties (as-received) and stoichiometric air-fuel ratio.

\begin{tabular}{cccc}
\hline & Biomass Pellets & Wood Waste & RDF \\
\hline $\mathrm{C}, \mathrm{wt} \%$ & 44.49 & 33.32 & 43.00 \\
$\mathrm{H}, \mathrm{wt} \%$ & 5.25 & 4.09 & 5.30 \\
$\mathrm{O}, \mathrm{wt} \%$ & 42.4 & 41.3 & 32.68 \\
$\mathrm{~N}, \mathrm{wt} \%$ & 1.28 & 1.39 & - \\
fixed carbon, wt $\%$ & 22 & 11.99 & 6.9 \\
volatiles, wt $\%$ & 67 & 47.44 & 61.8 \\
moisture, wt $\%$ & 9 & 26.1 & 17.9 \\
ash, wt $\%$ & 2 & 14.47 & 13.4 \\
density, $\mathrm{kg} / \mathrm{m}^{3}$ & 1000 & 714 & 810 \\
stoichiometric air & 5.51 & 4.38 & 6.59 \\
bed height, cm & 20 & 20 & 20 \\
$\mathrm{HHV}, \mathrm{MJ} / \mathrm{kg}$ & 18.72 & 13.58 & 14.60 \\
\hline
\end{tabular}

The fuel properties are used within the developed model in order to compare the combustor's properties under different feeding fuel conditions. The temperature contour of the fuel bed conversion for each fuel is shown in Figure 5. The reaction front in moving grate boilers with cross-current flow regime propagates from bed surface downward the grate (the first phase), and then inversely from the grate toward the surface of the bed, until the fuels would be completely burned (the second phase). The first phase of reaction front for the system fed with biomass pellets finished earlier, by $11 \mathrm{~min}$, compared to other fuel options by 15 and $18 \mathrm{~min}$ for wood waste and RDF, respectively. This can be attributed to the fact that biomass pellets contain less moisture content than the other two fuels. In the second phase, however, fuel with less fixed carbon content experiences a shorter conversion time. Furthermore, it can be concluded that the maximum temperature inside the fuel bed has a direct correlation with the fixed carbon content of the fuel. From the system adaptation view, since the complete combustion of biomass pellets, wood waste, and RDF requires $42.8 \mathrm{~min}, 35.23 \mathrm{~min}$, and $34.56 \mathrm{~min}$ correspondingly, for a grate length of $2 \mathrm{~m}$, the grate velocity must be regulated by $0.77 \mathrm{~mm} / \mathrm{s}, 0.94 \mathrm{~mm} / \mathrm{s}$, and $0.96 \mathrm{~mm} / \mathrm{s}$, respectively. Moreover, as drying, pyrolysis, and char oxidation happen in different lengths of the grate, the primary air distribution should be updated by the wind-box mechanism under the grate, in order to speed up the conversion process inside the fuel bed. According to Yin et al. [42,46], about $40 \%$ of primary air is injected to the fuel bed from the grate opening until complete volatile decomposition, and the rest of air is distributed between middle and last zone with a ratio of 2:1. In the utilized biomass combustor, three equal wind-boxes are equipped under the grate in which the primary air is distributed for an efficient conversion. Here, Table 4 is proposed in order to adapt primary air distribution of biomass bed regarding each waste fuel. 


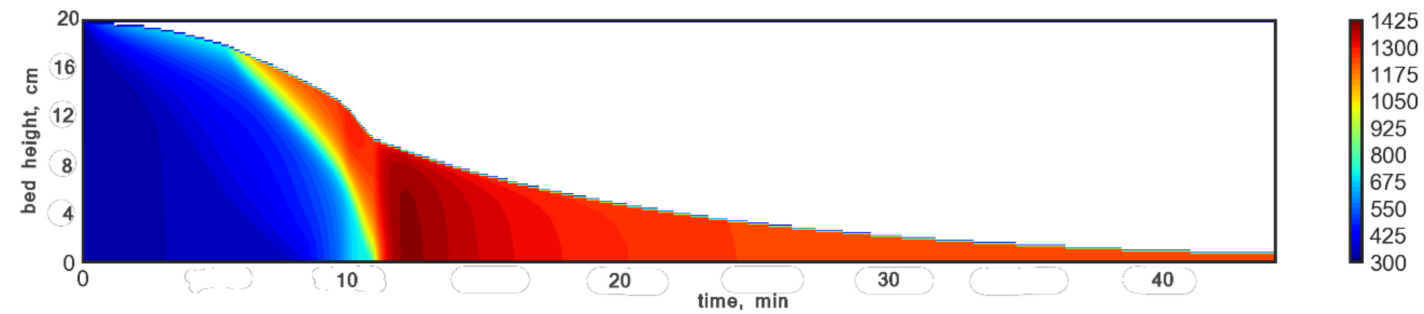

(a)

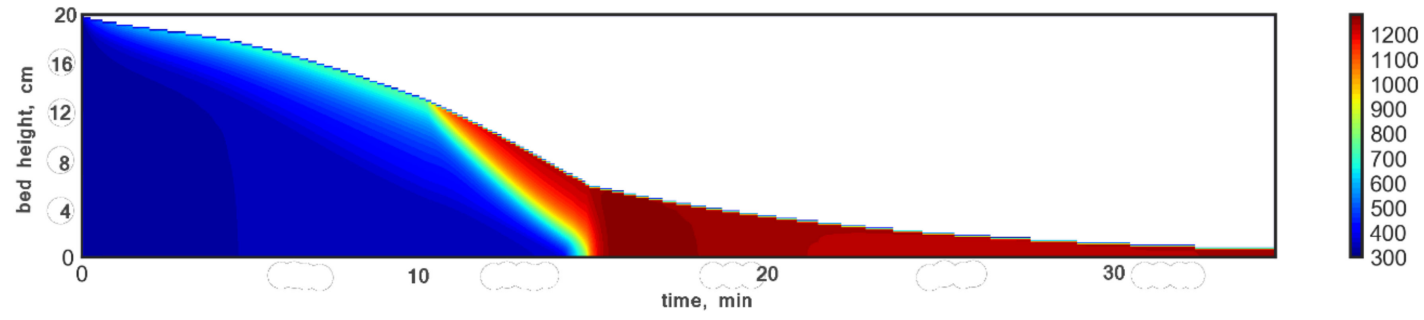

(b)

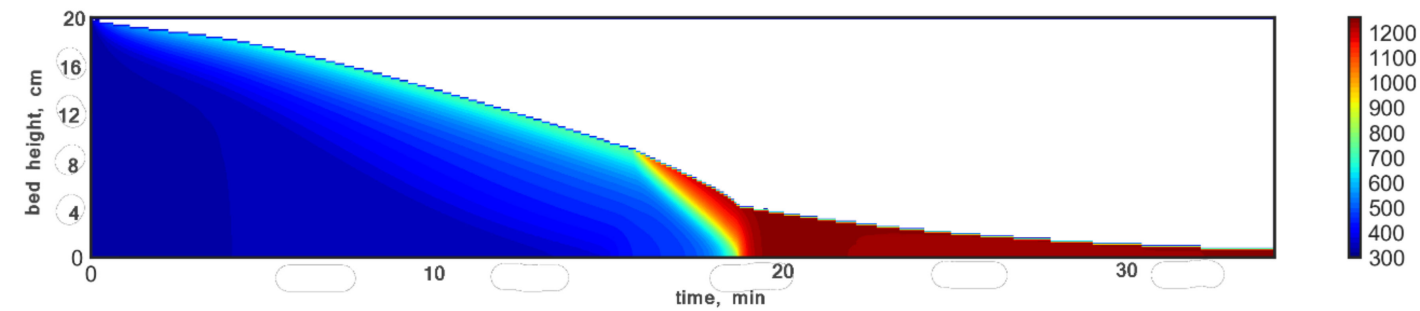

(c)

Figure 5. Contour of solid temperature for combustion of: (a) biomass pellets, (b) wood waste, (c) refuse-derived fuel (RDF).

Table 4. Primary air distribution of biomass combustor for different fuels.

\begin{tabular}{cccc}
\hline & Zone 1 & Zone 2 & Zone 3 \\
\hline Biomass pellets & $40 \%$ & $40 \%$ & $20 \%$ \\
Wood waste & $25 \%$ & $50 \%$ & $25 \%$ \\
RDF & $20 \%$ & $55 \%$ & $25 \%$ \\
\hline
\end{tabular}

To elaborate on the mass loss of each proposed fuel during the combustion process, dashed-line profiles in Figure 6 are referred to. From the figure, it is clear that, despite the lack of similarity between the bed decay of wood waste and RDF, the mass loss behavior is quite similar, while the biomass pellet shows a different trend. The mass-loss rate of wood waste and RDF in drying stage outperform biomass pellet because of less fuel particle density; nevertheless, as the moisture content of biomass pellet is far less than others, its devolatilization stage is triggered earlier and consequently, its mass loss dominates two other ones for a few minutes. In the final stage that char starts to burn out, again, wood waste and RDF mass loss surpass the biomass pellet, owing to less density and fixed carbon content.

Solid particle temperature profiles of bed surface regarding each biomass fuel are shown in Figure 6, in which the decelerating effect of moisture content on temperature evolution is demonstrated. In the char combustion step, the temperature becomes converged, as there is no difference between all particles. Due to the fact that biomass pellets include less moisture and more char content, the temperature rise takes place in the shorter grate length and results in higher heat generation per grate length for pellets, which will be quantified later on. 


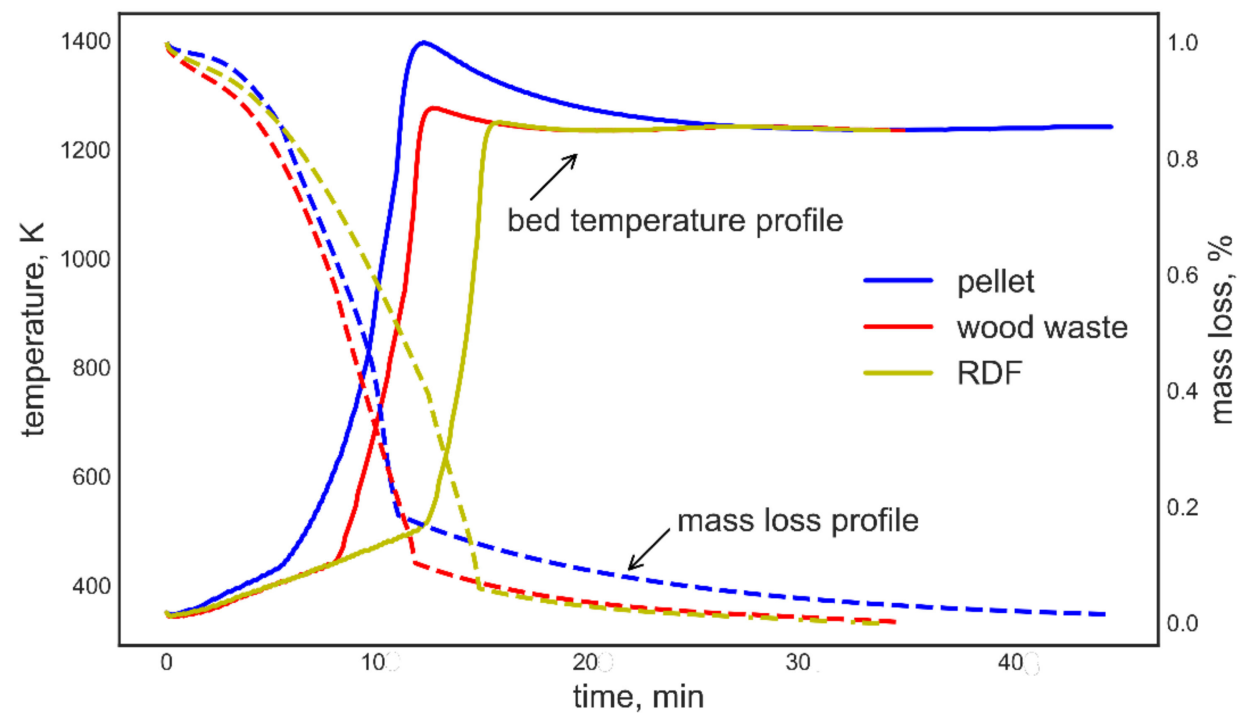

Figure 6. Mass loss (dashed-line) and temperature evolution (solid line) profiles of thethree fuels.

Volumetric concentration in terms of mole per hour for all emitting gas from the moving fuel bed is illustrated as Figure 7. Higher water vapor of the wood waste and RDF than the pellets was expected, due to more moisture content in the fuel. The carbon monoxide outflowing rate for RDF dominates one for wood waste, which can be interpreted by higher volatile matter, whereas the carbon dioxide rate originating from fixed carbon content was inversely higher for wood waste. Among the emitting gas species from fuel bed conversion, $\mathrm{CO}_{2}$ and $\mathrm{H}_{2} \mathrm{O}$ remain neutral and ones that were listed through Equations (2)-(5), which react with oxygen together with heat flux from char oxidation and form the heat source in the system. Useful output heat of the combustor can be calculated using Equation (6), where $N_{f}$ is mole of fuel, $h_{s, f}$ sensible enthalpy of fuel, $h_{s, i}$ sensible enthalpy of each products, $h_{f g}$ latent heat of water vapor, and $q_{\text {loss }}$ is heat leakage [47]. It is assumed that flue gases leave the stack at the temperature $400 \mathrm{~K}$.

$$
q=h_{s, f}+H H V+\frac{N_{a i r}}{N_{f}} h_{s, a i r}-\sum_{i=1}^{I} \frac{N_{i}}{N_{f}} h_{s, i}-\frac{N_{H 2 O}}{N_{f}} h_{f g}-\frac{q_{\text {loss }}}{\dot{N}_{f}}
$$

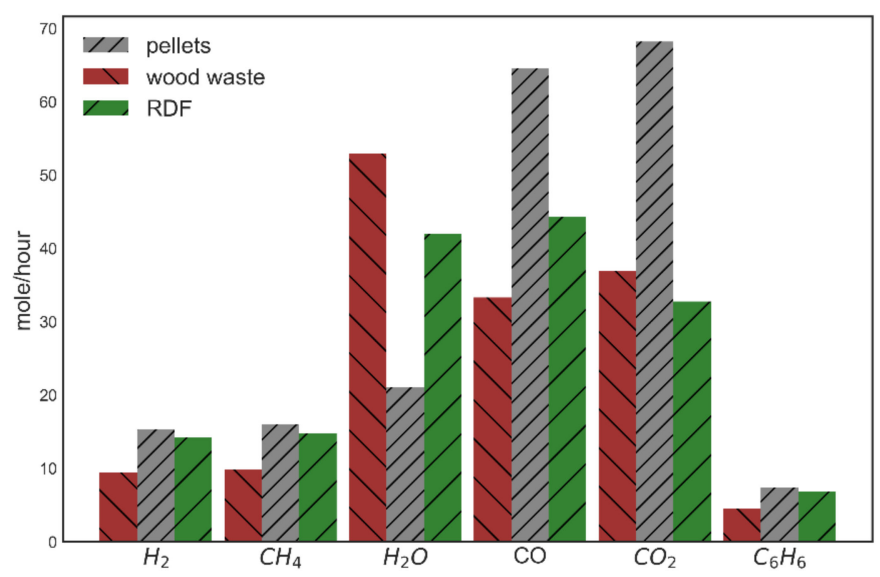

Figure 7. Volumetric concentration of emitting gases from fuel bed.

According to the outcomes, the useful heat flux per $\mathrm{kg}$ of the wet biomass pellets was obtained at $15.282 \mathrm{MJ}$, while it lowered by $32 \%$ and $30 \%$ for wood waste and RDF, respectively. It must be noted that water vapor is not condensed within the combustor, which wastes a notable amount of heat. 
Taking the conversion rate of each fuel into the account given in Table 5, annual heat generation from the proposed system was attained at 548 GJ for biomass pellets, contrasted with $48 \%$ and $35 \%$ lower in terms of wood waste and RDF. Here, the point worth making is that operating time has assumed being on full-load whole year. It was similarly concluded that for complete combustion of biomass pellets, a residence time of $42.8 \mathrm{~min}$ must be accounted for, and it must be updated when wood waste or RDF are deployed.

Table 5. Operational characteristics of the heating system for each fuel.

\begin{tabular}{cccc}
\hline & Biomass Pellets & Wood Waste & RDF \\
\hline Heat generation, $\mathrm{MJ} / \mathrm{kg}$ & 15.282 & 10.379 & 10.569 \\
Conversion rate, $\mathrm{kg} / \mathrm{h}$ & 4.10 & 3.107 & 3.84 \\
Annual energy generation, GJ/annual & 548.868 & 282.488 & 355.524 \\
Maximum bed temperature, K & 1396 & 1276 & 1249 \\
Residence time, min & 42.8 & 35.23 & 34.56 \\
Flame temperature with 100\% total excess air, K & 1477 & 1490 & 1537 \\
\hline
\end{tabular}

Gas species concentration emitted from the bed reactions are taken to find the flame temperature of the overbed zone via a black-box method. Due to the high air infiltrations rate in moving bed biomass boilers, the flame temperature is much lower than stoichiometric condition in practice. According to the literature [48,49], excess air coefficient usually changes between 1.2-3 for such systems, and the total excess air ratio of 2 is utilized here. This unwanted excess air causes significant heat loss through the combustion chamber. Although applying a screw feeder can mitigate this, it still poses a great challenge against moving bed combustor. Lower flame temperature of pellets to other fuels can be attributed to higher $\mathrm{CO} / \mathrm{H}_{2}$ ratio, because the hydrogen flame temperature is almost $200^{\circ} \mathrm{C}$ higher.

\subsection{Economic Analysis}

In this section, the proposed biomass combustor under each feeding fuel condition are economically investigated for the hot water supply applications. The biomass combustor is considered in a hot water supply system equipped with hot water tanks, piping and instruments, and water circulating pumps. The approaches such as net present value (NPV), internal rate of return (IRR), annual cost (AC), and so on, have been used within the existing literature [50,51]. In this article, in addition to NPV and AC analysis of the operating system, IRR will be also addressed, in order to make the analysis more comprehensive. The AC indicator serves up a powerful metric for contrasting the costs of various equipment, especially for those with low capital and high operational costs and vice versa.

The cost of producing energy from the proposed fuels depends on the system's capital cost $\left(\mathrm{C}_{\mathrm{c}}\right)$, installation cost $\left(C_{i n}\right)$, fuel storage cost $\left(C_{s t}\right)$, fuel cost $\left(C_{f}\right)$, electricity cost $\left(C_{e l}\right)$, maintenance cost $\left(C_{m}\right)$, unseen $\operatorname{cost}\left(\mathrm{C}_{\mathrm{un}}\right)$, and salvation $\operatorname{cost}\left(\mathrm{C}_{\mathrm{s}}\right)$. The salvation cost is the income at the end of system lifetime associated with equipment disposal. Table 6 displays the relevant values regarding the aforementioned parameters for the $25 \mathrm{~kW}$ biomass boiler, which can be updated via Equation (7) for variant system size [50-53]. In this research, the capacity of the proposed biomass boiler is $30 \mathrm{~kW}$, therefore, the capital, installation, and electricity cost are updated in the calculation.

$$
C=C_{0}\left(\frac{N}{N_{0}}\right)^{g}
$$

where $\mathrm{C}$ and $\mathrm{C}_{0}$ are the capital cost of the new system and base system, and $\mathrm{N}$ and $\mathrm{N}_{0}$ are system capacity corresponding alongside factor $\mathrm{g}$, ranging from $0.4-0.8$ for process equipment. Hence, the life cycle cost $\left(\mathrm{C}_{\mathrm{LCC}}\right)$ of energy generation during the system's lifespan, of 25 years will be as follows:

$$
C_{L C C}=C_{c}+C_{i n}+C_{s t}-C_{s}+\sum_{p=1}^{n} \frac{(1+c)^{p}}{(1+i)^{p}}\left(C_{f}+C_{e l}+C_{m}+C_{u n}\right)
$$


where $c$ and $i$ are escalation rate $4 \%$ and interest rate $2 \%$, respectively. In this way, the annualized cost $\left(C_{a}\right)$ can be obtained from Equation (9) which is a function of capital recover factor (e), achieved from interest rate (i) and equipment lifespan (n), as pointed out via Equation (10). Eventually, the cost of heat $(\mathrm{COH})$ using annual generated heat $Q_{a n n}$ and the annualized cost is calculated by Equation (11). Additionally, the IRR, which is the interest rate at which the NPV of every cash flow during the lifespan of a project becomes zero, is counted via Equation (12) where CF means annual cash flow.

$$
\begin{gathered}
C_{a}=e \cdot C_{L C C} \\
e=\frac{i(1+i)^{n}}{(1+i)^{n}-1} \\
C O H=\frac{C_{a}}{Q_{a n n}} \\
\sum_{p=0}^{n} \frac{C F_{p}}{(1+I R R)^{p}}=0
\end{gathered}
$$

The results of the economic analysis are presented in Table 7. Levelized $\mathrm{COH}$ reveals that RDF has the lowest heat price by $7.63 \mathrm{c} / \mathrm{kWh}$, compared to 8.23 and $9.80 \mathrm{c} / \mathrm{kWh}$ for pellets and wood waste correspondingly, which can be attributed to the lower fuel cost of RDF. Although the annualized cost of heat from the pellet-fueled system is about $64 \%$ more than other ones, because of the corresponding higher annual heat production, the related $\mathrm{COH}$ factor has a marginal difference with two other options. Taking the wood waste heat price into account, which is the highest reported value between all options in Table 7, it still outperforms the US national average residential rate of $11.88 \mathrm{c} / \mathrm{kWh}$, regardless of potential government incentives supporting the energy generation from cleaner resources [54]. The LCC breakdown for each particular scenario, as demonstrated in Figure 8, reveals the sway of fuel cost over the total life cycle cost of the system followed by system capital cost invested in the first year. Here, in Figure 8, the capital and installation costs are aggregated in capital cost term, which is roughly $14 \%$ for biomass pellet and $19 \%$ and $20 \%$ for wood waste and RDF, consecutively. Finally, higher IRR of pellets to RDF, in spite of lower $\mathrm{COH}$ of $\mathrm{RDF}$, is explained by the fact that the boiler generates higher annual heat rate under the pellet's feeding conditions.

Table 6. List of breakdown costs for biomass boiler heating system [50].

\begin{tabular}{ccc}
\hline Cost Type & Description & Cost (\$) \\
\hline capital cost, $C_{\mathrm{c}}$ & $25 \mathrm{~kW}$ biomass boiler and accessories & $13,800-15,300$ \\
installation cost, $C_{\text {in }}$ & piping, pumps, valves, and labour, etc. & $9000-11,500$ \\
fuel storage cost, $C_{\text {st }}$ & outdoor storage room & $1000-2000$ \\
& biomass pellet & $150 /$ ton \\
fuel cost, $C_{\mathrm{f}}$ & wood waste & $90 /$ ton \\
& RDF & $70 /$ ton \\
electricity cost, $C_{\mathrm{el}}$ & boiler electricity usage & $40 /$ month \\
maintenance cost, $C_{\mathrm{m}}$ & cleaning and non-technical maintenance & $0.01^{*}\left(C_{c}+C_{i n}+C_{s t}\right)$ \\
unseen cost, $C_{\mathrm{un}}$ & system design and loss risks, etc. & $0.01^{*}\left(C_{c}+C_{i n}+C_{s t}\right)$ \\
salvation cost, $C_{\mathrm{s}}$ & system disposal & $0.05^{*} C_{c}$ \\
\hline
\end{tabular}

Table 7. Economic analysis conclusion for the system under different fuel conditions.

\begin{tabular}{cccc}
\hline & Biomass Pellets & Wood Waste & RDF \\
\hline$N P V, \$$ & 230,622 & 141,420 & 138,540 \\
$C_{a}, \$$ & 12,517 & 7675 & 7519 \\
$\mathrm{COH}, \mathrm{c} / \mathrm{kWh}$ & 8.23 & 9.80 & 7.63 \\
$\mathrm{IRR}$ & $36 \%$ & $18 \%$ & $26 \%$ \\
\hline
\end{tabular}




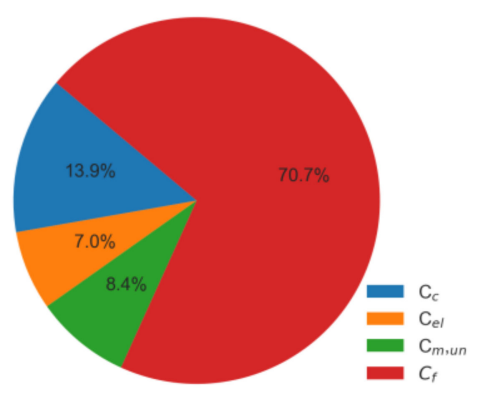

(biomass pellet)

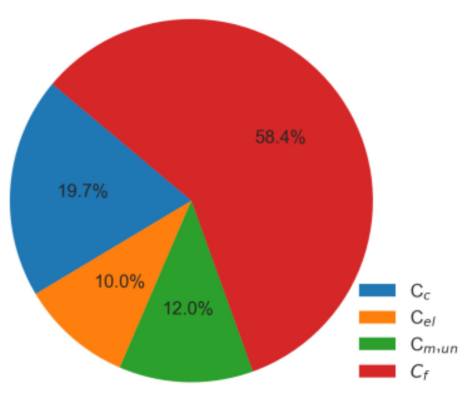

(wood waste)

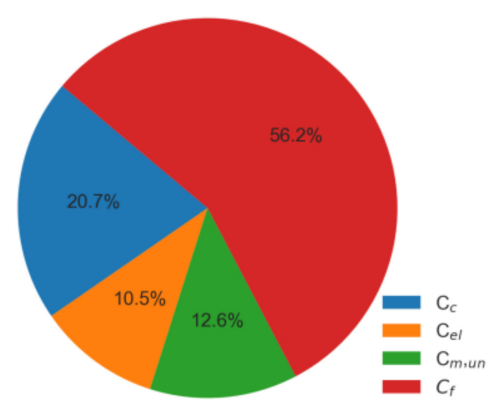

(RDF)

Figure 8. Life cycle cost contribution for $30 \mathrm{~kW}$ biomass boiler; $\mathrm{C}_{\mathrm{c}}$ : capital cost, $\mathrm{C}_{\mathrm{el}}$ : electricity cost, $\mathrm{C}_{\mathrm{m}, \mathrm{un}}$ : maintenance+unseen cost, $\mathrm{C}_{\mathrm{f}}$ : fuel cost.

\subsection{Environmental Analysis}

Ordinarily, the production, collection, and exploitation of the proposed fuels are associated with a variety of combinations of environmental profits and losses. From the literature, the boundary of LCA could vary from the very beginning of the process cycle to the very end of that, corresponding to the subjects of the study $[55,56]$. Negative impacts of the collection and treatment of raw fuels are compensated and even surpassed during the replacement of fossil fuels with these alternatives in combustion systems, leading to emission discount. An LCA approach is applied in this section, in order to compare the environmental impacts of each alternative fuel. The LCA boundary from fuel preparation until the heat generation for proposed fuels is depicted in Figure 9. Considering the aim is to compare the impact of each fuel utilization on the ecosystem, the same heat production is assumed for all scenarios. Table 8 lists the main input data employed in the LCA. The system operating site is located in Alma, Quebec, Canada where the closest fuel supplier is in distance of $160 \mathrm{~km}$ [57]. The boiler electricity consumption rate was assumed to be equal for all waste fuel scenarios. The quantity of emitting pollutants from each fuel combustion was accounted via the built-in SimaPro database. SimaPro software and relevant database for North America (TRACI 2.1) was employed for pollutant indices calculations. It must be mentioned that fuels originated from wood resources are deemed neutral $\mathrm{CO}_{2}$, and, therefore, no carbon dioxide emission is counted during the combustion process in LCA calculation, while RDF as a mixture of biogenic and inorganic materials, so it does emit $\mathrm{CO}_{2}$ in the combustion process.

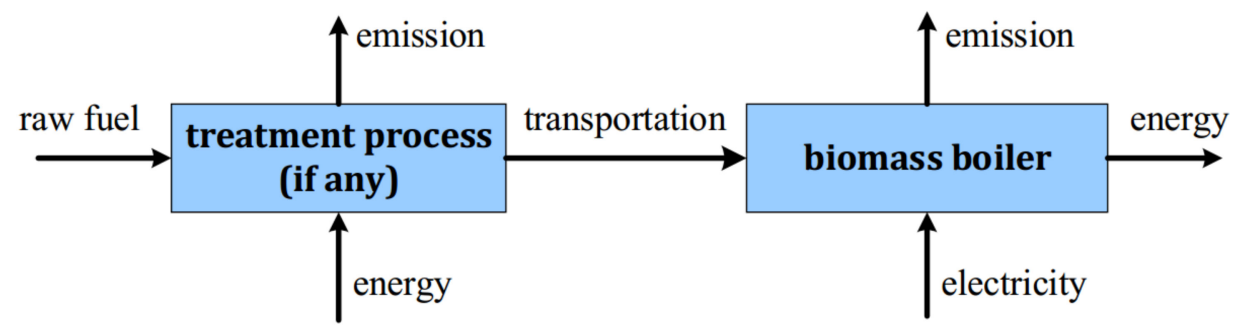

Figure 9. System boundary for the LCA implementation.

Table 8. Input data for life cycle analysis (LCA) of biomass pellets, wood waste, and RDF individually.

\begin{tabular}{cccc}
\hline & Biomass Pellets & Wood Waste & RDF \\
\hline system load, $\mathrm{GJ}$ & 512 & 512 & 512 \\
transportation, tkm & 5378 & 7919 & 7777 \\
boiler electricity use, $\mathrm{kWh} / \mathrm{yr}$ & 4576 & 4576 & 4576 \\
treatment process & $\boldsymbol{N}$ & $\mathrm{N}$ & $\mathbf{X}$ \\
$\mathrm{CO}_{2}$ emission $\mathrm{kg} / \mathrm{ton}$ & $\mathrm{N} / \mathrm{A}$ & $\mathrm{N} / \mathrm{A}$ & 650 \\
\hline
\end{tabular}


The results of the environmental analysis are demonstrated in Table 9, based on different impacts. To acquire a certain impact indicator, different factors must be combined into one prevailing factor. For instance, the value of $\mathrm{CH}_{4}$ is converted to the equivalent of the $\mathrm{CO}_{2}$ amount using the relevant conversion factor, 21, and is then added to the basic $\mathrm{CO}_{2}$ amount to represent the total equivalent $\mathrm{CO}_{2}$ for global warming impact [58]. On the same heat generation, RDF environmentally becomes more destructive in global warming, smog, and acidification factors than others, while the biomass pellets have the worst impact on ozone depletion, eutrophication, carcinogenic, and ecotoxicity, but have the most positive effect on fossil fuel depletion. Environmentally speaking, wood waste is seen as the least harmful fuel, mainly due to avoiding high fuel preprocessing.

Table 9. Results of life cycle impact analysis for the heating system fed with proposed fuels.

\begin{tabular}{ccccc}
\hline Impact Category & Unit & Biomass Pellets & Wood Waste & RDF \\
\hline ozone depletion & $\mathrm{kg} \mathrm{CFC-11} \mathrm{eq}$ & 0.001522529 & 0.000922053 & 0.000869097 \\
global warming & $\mathrm{kg} \mathrm{CO}$ eq & $11,646.90$ & 4720.67 & $37,993.95$ \\
smog & $\mathrm{kg} \mathrm{O}$ eq & 3633.39 & 1660.60 & 3622.09 \\
acidification & $\mathrm{kg} \mathrm{SO}$ eq & 148.78 & 66.24 & 213.57 \\
eutrophication & $\mathrm{kg} \mathrm{N} \mathrm{eq}$ & 52.86 & 4.73 & 7.97 \\
carcinogenics & $\mathrm{CTUh}$ & 0.000368746 & $5.549 \times 10^{-5}$ & $4.48904 \times 10^{-5}$ \\
on-carcinogenics & $\mathrm{CTUh}$ & 0.0022399 & 0.000330273 & 0.000270265 \\
respiratory effects & $\mathrm{kg}$ PM2.5 eq & 8.86 & 2.10 & 2.50 \\
ecotoxicity & CTUe & $64,572.91$ & $10,768.19$ & 8865.58 \\
fossil fuel depletion & MJ surplus & $21,370.00$ & $11,928.03$ & $11,449.94$ \\
\hline
\end{tabular}

Global warming impacts are probably the most concerning factor among all sorted items in Table 9. From the results, the RDF has a negative impact in terms of global warming three times greater than that of biomass pellets, mainly caused by emitted $\mathrm{CO}_{2}$ in combustion. In order to elaborate on the contribution of each particular subprocess on emitting greenhouse gases, Figure 10, is displayed and only shows the top three substantial affecting contributors. By switching between alternative fuels from biomass pellets to wood waste and RDF, the key contributor to the greenhouse emission is the pelletizing process, electricity use by the boiler, and pollutant emission from RDF combustion combined.

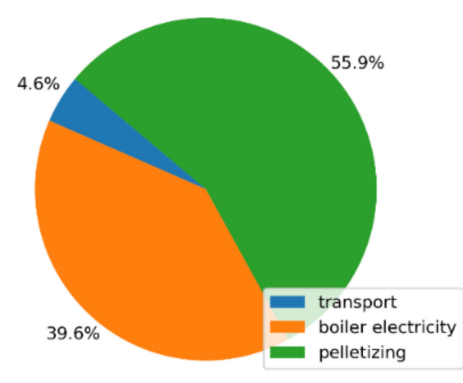

(biomass pellets)

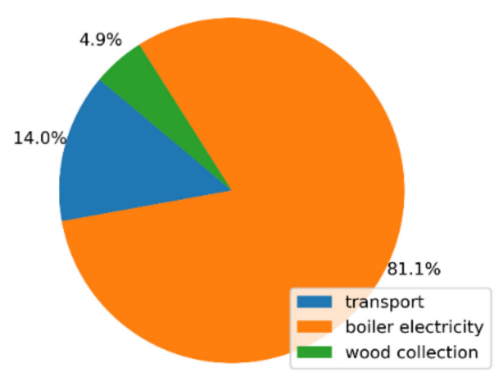

(wood waste)

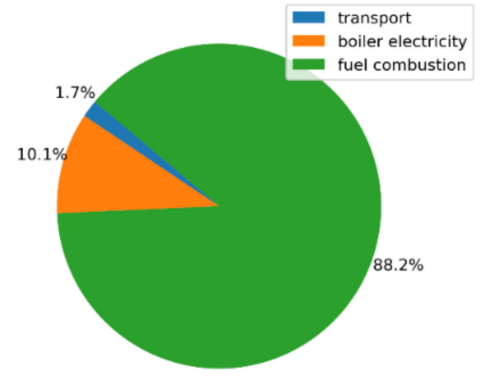

(RDF)

Figure 10. Proportion of three key contributors to the greenhouse gases for each feeding fuel.

\section{Conclusions}

In this article, a thermo-economic and environmental analysis was conducted for a moving grate biomass boiler to compare the utilization of three variant waste fuels, including biomass pellets, wood waste, and RDF in the proposed system. Fuel conversion inside the fuel bed was delicately modeled using an in-house routine numerical model. The useful heat flux from the boiler was calculated through an overbed black-box model based upon each feeding fuel, and the required time of complete fuel combustion was determined. It was concluded that biomass pellets deliver the highest system 
thermal efficiency so that the pellet-fueled system provides 548 GJ heat annually, opposite to $282 \mathrm{GJ}$ utilizing wood waste, and 355 GJ utilizing RDF. Furthermore, the maximum solid bed temperature for biomass pellets is about $11 \%$ higher than the estimation in the RDF scenario. This is mainly because of the higher fixed-carbon content of biomass pellets. Moreover, a separate comprehensive economic analysis was practiced for the proposed biomass boiler with respect to each alternative fuel, and, again, the results revealed the privilege of using biomass pellets among all other waste fuels. Although the $\mathrm{COH}$ of RDF scenario was lowest by $7.63 \mathrm{~m} / \mathrm{kWh}$, which was $7 \%$ and $22 \%$ less than biomass pellets and wood waste respectively, the IRR of the pellet-fueled system was highest by $36 \%$, because of its higher heating capacity compared to all others. Regardless of the scenario, the fuel cost reserved the most contribution to the total life cycle cost of heat production. In the last section of the article, a comparative LCA ratified the importance of employing fuels with no carbon footprint. The $\mathrm{CO}_{2}$ emission from the RDF combustion was obtained far higher than other plant-based fuels, which were counted as $\mathrm{CO}_{2}$ neutral emission.

Biomass boilers should be considered to be promising facilities for heating supply in remote areas [59]. In future studies, it is recommended to investigate the deployment of combustible waste from cargo ships for heating purposes from thermo-economic and environmental viewpoints. Carrying waste is problematic for shipping companies. On the other hand, the randomness of fuel arrangements inside the fuel bed, along with fuel constituents, and size uncertainty, are some challenges encountering biomass combustor operation and modeling in the present day. Quantifying the relevant effects on the system operation is recommended. Lastly, the LCA system boundary of this study was limited to some degree, which can be extended up to the very beginning and very end for future works.

Author Contributions: M.H.R., corresponding author, conducted the literature review on subject and provided the research gap. He performed the mathematical modeling, solution algorithm coding, and analysis and presentation the results. F.N., oversaw the entire article materials and verified the modeling and results. Meanwhile, he fulfilled proofreading of the final version of article. All authors have read and agreed to the published version of the manuscript.

Funding: This research received no external funding.

Conflicts of Interest: The authors declare no conflict of interest.

\section{References}

1. Liu, X.; Feng, X.; Huang, L.; He, Y. Rapid Determination of Wood and Rice Husk Pellets' Proximate Analysis and Heating Value. Energies 2020, 13, 3741. [CrossRef]

2. Singh, V.; Phuleria, H.C.; Chandel, M.K. Estimation of energy recovery potential of sewage sludge in India: Waste to watt approach. J. Clean. Prod. 2020, 276, 122538. [CrossRef]

3. Heidari, M.; Salaudeen, S.A.; Norouzi, O.; Acharya, B.; Dutta, A. Numerical Comparison of a Combined Hydrothermal Carbonization and Anaerobic Digestion System with Direct Combustion of Biomass for Power Production. Processes 2020, 8, 43. [CrossRef]

4. Camacho, C.E.G.; Ruggeri, B.; Mangialardi, L.; Persico, M.; Malavé, A.C.L. Continuous two-step anaerobic digestion (TSAD) of organic market waste: Rationalising process parameters. Int. J. Energy Environ. Eng. 2019, 10, 413-427. [CrossRef]

5. Safari, F.; Norouzi, O.; Tavasoli, A. Hydrothermal gasification of Cladophora glomerata macroalgae over its hydrochar as a catalyst for hydrogen-rich gas production. Bioresour. Technol. 2016, 222, 232-241. [CrossRef]

6. Safari, F.; Javani, N.; Yumurtaci, Z. Hydrogen production via supercritical water gasification of almond shell over algal and agricultural hydrochars as catalysts. Int. J. Hydrogen Energy 2018, 43, 1071-1080. [CrossRef]

7. Da Costa, T.P.; Quinteiro, P.; Tarelho, L.A.D.C.; Arroja, L.M.; Dias, A.C. Environmental impacts of forest biomass-to-energy conversion technologies: Grate furnace vs. fluidised bed furnace. J. Clean. Prod. 2018, 171, 153-162. [CrossRef]

8. Gómez, M.; Martín, R.; Chapela, S.; Porteiro, J. Steady CFD combustion modeling for biomass boilers: An application to the study of the exhaust gas recirculation performance. Energy Convers. Manag. 2019, 179, 91-103. [CrossRef] 
9. Zhou, A.; Xu, H.; Tu, Y.; Zhao, F.; Zheng, Z.; Yang, W. Numerical investigation of the effect of air supply and oxygen enrichment on the biomass combustion in the grate boiler. Appl. Therm. Eng. 2019, 156, 550-561. [CrossRef]

10. Xu, Y.; Zhai, M.; Jin, S.; Zou, X.; Liu, S.; Dong, P. Numerical simulation of high-temperature fusion combustion characteristics for a single biomass particle. Fuel Process. Technol. 2019, 183, 27-34. [CrossRef]

11. Chowdhury, M.S.R.; Azad, A.; Karim, R.; Naser, J.; Bhuiyan, A.A. Reduction of GHG emissions by utilizing biomass co-firing in a swirl-stabilized furnace. Renew. Energy 2019, 143, 1201-1209. [CrossRef]

12. González, W.A.; Perez, J.F.; Chapela, S.; Porteiro, J. Numerical analysis of wood biomass packing factor in a fixed-bed gasification process. Renew. Energy 2018, 121, 579-589. [CrossRef]

13. Yu, Z.; Ma, X.; Liao, Y. Mathematical modeling of combustion in a grate-fired boiler burning straw and effect of operating conditions under air- and oxygen-enriched atmospheres. Renew. Energy 2010, 35, 895-903. [CrossRef]

14. Bin, Z. Solid oxide fuel cell (SOFC) technical challenges and solutions from nano-aspects. Int. J. Energy Res. 2009, 31, 135-147. [CrossRef]

15. Lv, Q.; Wang, C.; Liu, X.; Du, Y.; Li, D.; Che, D. Combustion and heat transfer characteristics of co-firing biomass and coal under oxy-fuel condition. Int. J. Energy Res. 2018, 42, 4170-4183. [CrossRef]

16. Li, J.; Paul, M.; Younger, P.L.; Watson, I.; Hossain, M.; Welch, S. Prediction of high-temperature rapid combustion behaviour of woody biomass particles. Fuel 2016, 165, 205-214. [CrossRef]

17. Rezeau, A.; Díez, L.I.; Royo, J.; Díaz-Ramírez, M. Efficient diagnosis of grate-fired biomass boilers by a simplified CFD-based approach. Fuel Process. Technol. 2018, 171, 318-329. [CrossRef]

18. Karim, R.; Bhuiyan, A.A.; Naser, J. Effect of recycled flue gas ratios for pellet type biomass combustion in a packed bed furnace. Int. J. Heat Mass Transf. 2018, 120, 1031-1043. [CrossRef]

19. Zhou, A.; Xu, H.; Yang, W.; Tu, Y.; Xu, M.; Yu, W.; Boon, S.K.; Subbaiah, P. Numerical Study of Biomass Grate Boiler with Coupled Time-Dependent Fuel Bed Model and Computational Fluid Dynamics Based Freeboard Model. Energy Fuels 2018, 32, 9493-9505. [CrossRef]

20. Rahdar, M.H.; Lee, B.; Nasiri, F. Uncertainty Quantification of Biomass Composition Variability Effect on Moving-Grate Bed Combustion: An Experiment-Based Approach. Energy Fuels 2020, 34, 9697-9708. [CrossRef]

21. Nunes, L.J.; Godina, R.; Matias, J.C.; Catalão, J.P. Economic and environmental benefits of using textile waste for the production of thermal energy. J. Clean. Prod. 2018, 171, 1353-1360. [CrossRef]

22. Kumar, H.; Mohapatra, S.K.; Singh, R.I. Review on CFD Modelling of Fluidized Bed Combustion Systems based on Biomass and Co-firing. J. Inst. Eng. Ser. C 2017, 99, 449-474. [CrossRef]

23. Cereijo, G.N.; Curto-Risso, P.L.; Bizzo, W.A. Simplified model and simulation of biomass particle suspension combustion in one-dimensional flow applied to bagasse boilers. Biomass Bioenergy 2017, 99, 38-48. [CrossRef]

24. Gómez, M.; Porteiro, J.; Patiño, D.; Miguez, J. Fast-solving thermally thick model of biomass particles embedded in a CFD code for the simulation of fixed-bed burners. Energy Convers. Manag. 2015, 105, 30-44. [CrossRef]

25. Khodaei, H.; Yeoh, G.H.; Guzzomi, F.; Porteiro, J. A CFD-based comparative analysis of drying in various single biomass particles. Appl. Therm. Eng. 2018, 128, 1062-1073. [CrossRef]

26. Khodaei, H.; Al-Abdeli, Y.M.; Guzzomi, F.G.; Yeoh, G.H. An overview of processes and considerations in the modelling of fixed-bed biomass combustion. Energy 2015, 88, 946-972. [CrossRef]

27. Rahdar, M.H.; Nasiri, F.; Lee, B. A Review of Numerical Modeling and Experimental Analysis of Combustion in Moving Grate Biomass Combustors. Energy Fuels 2019, 33, 9367-9402. [CrossRef]

28. Dernbecher, A.; Dieguez-Alonso, A.; Ortwein, A.; Tabet, F. Review on modelling approaches based on computational fluid dynamics for biomass combustion systems. Biomass Convers. Biorefinery 2019, 9, 129-182. [CrossRef]

29. Kær, S.K. Numerical modelling of a straw-fired grate boiler. Fuel 2004, 83, 1183-1190. [CrossRef]

30. Morgan-Sagastume, F.; Sleep, B.E.; Allen, D.G. Effects of Biomass Growth on Gas Pressure Drop in Biofilters. J. Environ. Eng. 2001, 127, 388-396. [CrossRef]

31. Duffy, N.T.; Eaton, J.A. Investigation of factors affecting channelling in fixed-bed solid fuel combustion using CFD. Combust. Flame 2013, 160, 2204-2220. [CrossRef]

32. Boriouchkine, A.; Jämsä-Jounela, S.-L. Simplification of a Mechanistic Model of Biomass Combustion for On-Line Computations. Energies 2016, 9, 735. [CrossRef] 
33. Roberts, R.C. Molecular diffusion of gases. In American Institute of Physics Handbook; McGraw-Hill: New York, NY, USA, 1972; pp. 249-252.

34. Shiehnejadhesar, A.; Scharler, R. Application of numerical modelling to biomass grate furnaces. Therm. Eng. 2015, 1, 550-556.

35. Miljković, B.; Pešenjanski, I.; Vićević, M. Mathematical modelling of straw combustion in a moving bed combustor: A two dimensional approach. Fuel 2013, 104, 351-364. [CrossRef]

36. Martinez-Garcia, J.; Nussbaumer, T. A One-Dimensional Transient Solid Fuel Conversion Model for Grate Combustion Optimization. Combust. Sci. Technol. 2015, 187, 1208-1228. [CrossRef]

37. Yang, W.; Ryu, C.; Choi, S. Unsteady one-dimensional model for a bed combustion of solid fuels. Proc. Inst. Mech. Eng. Part A J. Power Energy 2004, 218, 589-598. [CrossRef]

38. Fatehi, H.; Bai, X.-S. A Comprehensive Mathematical Model for Biomass Combustion. Combust. Sci. Technol. 2014, 186, 574-593. [CrossRef]

39. Li, C.; Suzuki, K. Process design and simulation of H2-rich gases production from biomass pyrolysis process. Bioresour. Technol. 2010, 101, S86-S90. [CrossRef]

40. Silva, J.; Teixeira, J.; Teixeira, S.F.; Preziati, S.; Cassiano, J. CFD Modeling of Combustion in Biomass Furnace. Energy Procedia 2017, 120, 665-672. [CrossRef]

41. Collazo, J.; Porteiro, J.; Patiño, D.; Granada, E. Numerical modeling of the combustion of densified wood under fixed-bed conditions. Fuel 2012, 93, 149-159. [CrossRef]

42. Mahmoudi, A.H. Prediction of Heat-Up, Drying and Gasification of Fixed and Moving Beds by the Discrete Particle Method (Dpm). Ph.D. Thesis, University of Luxembourg, Luxembourg, 2015.

43. Yin, C.; Rosendahl, L.; Kær, S.K.; Clausen, S.; Hvid, S.L.; Hille, T. Mathematical Modeling and Experimental Study of Biomass Combustion in a Thermal 108 MW Grate-Fired Boiler. Energy Fuels 2008, 22, 1380-1390. [CrossRef]

44. Porteiro, J.; Patiño, D.; Collazo, J.; Granada, E.; Moran, J.; Miguez, J. Experimental analysis of the ignition front propagation of several biomass fuels in a fixed-bed combustor. Fuel 2010, 89, 26-35. [CrossRef]

45. Rahdar, M.H.; Nasiri, F.; Lee, B. Effect of fuel composition uncertainty on grate firing biomass combustor performance: A Bayesian model averaging approach. Biomass Convers. Biorefinery 2020, 1-17. [CrossRef]

46. Kareem, B.; Oladosu, K.O.; Alade, A.O.; Durowoju, M.O. Optimization of combustion characteristics of palm kernel-based biofuel for grate furnace. Int. J. Energy Environ. Eng. 2018, 9, 457-472. [CrossRef]

47. Yin, C.; Rosendahl, L.; Clausen, S.; Hvid, S.L. Characterizing and modeling of an 88 MW grate-fired boiler burning wheat straw: Experience and lessons. Energy 2012, 41, 473-482. [CrossRef]

48. Ragland, K.W.; Bryden, K.M. Combustion Engineering; Taylor \& Francis Group: Oxford, UK, 2011; ISBN 9781466500013.

49. Gómez, M.; Comesaña, R.; Álvarez-Feijoo, M. Ángel; Eguía, P. Simulation of the Effect of Water Temperature on Domestic Biomass Boiler Performance. Energies 2012, 5, 1044-1061. [CrossRef]

50. Houshfar, E.; Skreiberg, Ø.; Løvås, T.; Todorović, D.; Sørum, L. Effect of Excess Air Ratio and Temperature on NOx Emission from Grate Combustion of Biomass in the Staged Air Combustion Scenario. Energy Fuels 2011, 25, 4643-4654. [CrossRef]

51. Wang, K.; Zhang, Y.; Sekelj, G.; Hopke, P.K. Economic analysis of a field monitored residential wood pellet boiler heating system in New York State. Renew. Energy 2019, 133, 500-511. [CrossRef]

52. Pradhan, P.; Gadkari, P.; Arora, A.; Mahajani, S. Economic feasibility of agro waste pelletization as an energy option in rural India. Energy Procedia 2019, 158, 3405-3410. [CrossRef]

53. Reza, B.; Soltani, A.; Ruparathna, R.; Sadiq, R.; Hewage, K. Environmental and economic aspects of production and utilization of RDF as alternative fuel in cement plants: A case study of Metro Vancouver Waste Management. Resour. Conserv. Recycl. 2013, 81, 105-114. [CrossRef]

54. Nabavi, V.; Azizi, M.; Tarmian, A.; Ray, C.D. Feasibility study on the production and consumption of wood pellets in Iran to meet return-on-investment and greenhouse gas emissions targets. Renew. Energy 2020, 151, 1-20. [CrossRef]

55. Residential Electricity Rates and Consumption in New York. Available online: https://www.electricitylocal. com/states/new-york/ (accessed on 1 September 2020).

56. Ferreira, J.; Viana, H.F.D.S.; Esteves, B.; Cruz-Lopes, L.P.G.O.V.; Domingos, I. Life cycle assessment of residual forestry biomass chips at a power plant: A Portuguese case study. Int. J. Energy Environ. Eng. 2014, 5, 1-7. [CrossRef] 
57. Tsalidis, G.A.; El Discha, F.; Korevaar, G.; Haije, W.; De Jong, W.; Kiel, J. An LCA-based evaluation of biomass to transportation fuel production and utilization pathways in a large port's context. Int. J. Energy Environ. Eng. 2017, 8, 175-187. [CrossRef]

58. Fuel Supplier Location. Available online: https://granulco.com/en/contact/ (accessed on 1 September 2020).

59. Adams, P.; McManus, M. Small-scale biomass gasification CHP utilisation in industry: Energy and environmental evaluation. Sustain. Energy Technol. Assess. 2014, 6, 129-140. [CrossRef]

Publisher's Note: MDPI stays neutral with regard to jurisdictional claims in published maps and institutional affiliations.

(C) 2020 by the authors. Licensee MDPI, Basel, Switzerland. This article is an open access article distributed under the terms and conditions of the Creative Commons Attribution (CC BY) license (http://creativecommons.org/licenses/by/4.0/). 